EISSN: $2706-7947$ ISSN: 2077- 4613

DOI: $10.36632 / \mathrm{mejas} / 2021.11 .3 .49$

Journal homepage: www.curresweb.com

Pages: 612-624

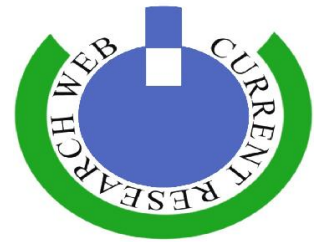

\title{
Effect of Some Natural Extracts as an Alternative to Chemical Growth Regulators on Rooting of the Terminal Stem Cuttings of Codiaeum variegatum "Gold Dust" Plant
}

\author{
A. S. El-Fouly ${ }^{1}$, A.W. Sayed ${ }^{1}$ and O. F. Abou El-leel ${ }^{2}$ \\ ${ }^{I}$ Ornamental Plants and Landscape Gardening Res. Dept., Hort. Res. Inst., ARC, Giza, Egypt. \\ ${ }^{2}$ Medicinal and Aromatic Plants Res. Dept., Hort. Res. Inst., ARC, Giza, Egypt.
}

Received: 10 June 2021

Accepted: 08 July 2021

Published: 15 July 2021

\begin{abstract}
An investigation was consummated under propagation greenhouse conditions at Al-Zohriya Garden, Hort. Res. Inst., Giza, Egypt during 2018 and 2019 seasons to study the effect of immersing the terminal stem cuttings of Codiaeum variegatum (L.) A. Juss. "Gold Dust" plant in the following solutions: distilled water (as control), the aqueous solution of cabbage leaf extract at 50 and $75 \%$ concentrations, the aqueous solution of molasses at 50 and $75 \%$ concentrations and that of indole-3-butyric acid (IBA) at 1500 and $3000 \mathrm{ppm}$ concentrations for either 15 or 30 minutes on rooting $\%$ and the initial growth traits of the produced transplants and chemical composition of their leaves. The obtained results indicated that various rooting solutions used in this study significantly increased the mean values of rooting\% with the superiority of submersing in the cabbage extract solution at $75 \%$ concentration, which gave the highest percentages in the two seasons over control and all the other treatments. Elongating immersing time from 15 to $30 \mathrm{~min}$. significantly improved the percent of rooting. Thus, combining between immersing in cabbage extract solution and immersing time of $30 \mathrm{~min}$. recorded the highest rooting percentage in both seasons. This combined treatment also attained the highest mean values of transplant growth characters (transplant length, number of both leaves and roots/ transplant, root length and fresh and dry weights of top growth and roots) compared to the individual and other combinations in the two seasons. Similarly, were those results of total chlorophyll $(a+b)$, carotenoids, $\mathrm{N}, \mathrm{P}, \mathrm{K}$, total carbohydrates, total indoles and total antioxidants concentrations in the leaves of the new formed transplants. However, the highest concentrations of both total phenols and total flavonoids were acquired by control treatment, but the different rooting solutions employed in such study significantly reduced their concentrations to reach the minimal values by soaking in $75 \%$ cabbage extract solution treatment relative to all the other ones. Accordingly, it is advised to soak the terminal cuttings of Codiaeum variegatum "Gold Dust" plant in the aqueous solution of cabbage leaf extract (75\% concentration) for 30 minutes as natural growth regulator to score the highest rooting rate and the best growth performance of the resulted transplants.
\end{abstract}

Keywords: Codiaeum variegatum "Gold Dust", rooting\%, natural extract, cabbage leaf extract, molasses, IBA.

\section{Introduction}

Codiaeum variegatum 'Gold Dust' is an evergreen shrub growing to $3 \mathrm{~m}$ tall and has large, thick, leathery, shiny evergreen leaves, alternately arranged. The stems contain milky sap that bleeds from cut stems. Croton 'Gold Dust' is a compact plant with elliptical to oval leaves which are medium green and liberally dusted with paint-like specks of yellow. Crotons grow best in well-drained soil. The leaves extract of crotons are reported to have many medicinal properties including purgative, sedative, antifungal, antiamoebic and anticancerous activities (Deshmukh \& Borle, 1975; Kupchan et al., 1976). It is native to southern India, Sri Lanka, Indonesia, Malaysia, and the western Pacific Ocean islands, growing in open forests and scrub (Huxley, 1992). 
Codiaeum variegatum cv. Gold Dust commonly known as Croton and sometimes called Joseph's coat, belongs to the Family Euphorbiaceae, is one of the most popular ornamental indoor plants because of colorful foliage colors and various leaf shapes. This plant is essential in decoration for purifying interior air (Esmail, 2008). It with variation of leaf types are one of the most popular plants in Egypt. It is one of the beautiful indoor and outdoor plants need extensive agriculture development (Ibrahim et al., 2010). Croton can be propagated by various methods such as cuttings, grafting, air layering and from shoot tip cuttings (Sana et al., 2012).

The medicinal value of Croton is due to the presence of some chemical substances that produce are alkaloids, carbohydrates, glycosides, steroids, flavonoids, coumarins, saponins, fatty acids, tannins, protein and amino acids, mucilage, terpenoids, anthroquinones and phenols. These chemicals can be exploited to synthesize future drugs (Bijekar and Gayatri, 2014). Codiaeum variegatum has a flexible response to various levels of light intensity. In different light intensity it shows different leaf colours. The shaded leaves are greener than the leaves exposed to sun. The mosaic pattern on the leaves may also be influenced by light intensity (Jena, 2016).

The outer leaves of cabbage (waste) that are peeled off before cabbages are distributed in the market were used as the raw material to produce bio-extract as a natural fertilizer on Mentha plant. Cabbage is a sulfur-rich plant because the glucosinolate accumulated in cabbage is able to breakdown to produce elemental sulfur, so, cabbage is a sulfur-rich plant. In this respect, cabbage waste contains minerals $(\mathrm{N}, \mathrm{P}, \mathrm{K}, \mathrm{Ca}, \mathrm{Mg}$, and $\mathrm{S}$ ), vitamins, and amino acids (aspartic, tryptophan, glycine, etc.), (Sitthithaworn et al., 2011).

Nutrients and phytochemicals raw cabbage contain $92 \%$ water, $6 \%$ carbohydrates, $1 \%$ protein, negligible fat, raw cabbage is a rich source of vitamin $\mathrm{C}$ and vitamin $\mathrm{K}$, containing $44 \%$ and $72 \% \mathrm{DV}$, respectively. Cabbage is also a moderate source (10-19\% DV) of vitamin B6, folate and indole-3carbinol (Wikipedia site, 2021).

Many ornamental plants are propagated by cuttings to get a great bulk of homogenous and identical progeny having the same characteristics of the parent plant suitable for importing and exporting purposes. However, success of this method mainly depends on the rapid generation of the new adventitious roots on cuttings, which are necessary for uptaking water and essential nutrients needed for promoting growth of the lateral buds on the cutting (Hartmann et al., 2002; Araya, 2005; Bester, 2013). Rooting success of stem cutting depends on many factors, amongst them using the rooting growth regulators, especially auxins that have been successfully employed in many plant species to improve the root ability of stem cuttings (Soundy et al., 2008; Singh et al.,2011; Saglam et al., 2014). These facts are documented by the results of Baldotto et al., (2012) on croton and Chinese hibiscus, El-Fouly et al., (2009) on Ficus deltoidea, El-Sayed et al., (2010 a) on Chinese hibiscus, El- Sayed et al., (2010 b) on Bougainvillea glabra, Balestri et al., (2012) on Ammophila arenaria and Sporobuls virginicus, Sevik et al., (2015) on Schefflera arboricola, Mabizela et al., (2017) on honeybush ( Cyclopia subternata), Goda et al., (2018) on Phytolacca dioica and Abdel- Rahman (2020) who found that cuttings of Conocarpus erectus treated with IBA at $100 \mathrm{ppm}$ concentration produced the highest rooting percentage (42.9\%) than $50 \mathrm{ppm}(36.3 \%), 200 \mathrm{ppm}(36 \%)$ and untreated cuttings $(23.1 \%)$. Root number, root length, stem length, branch number and leaf number of the resulted transplant were also the best by the same treatment.

Natural root promoting extracts as costless, safe and the most effective and convenient method is widely used at present for rooting rather than the synthetic hormones. Extracts of some natural resources like coconut water, willow leaf water, honey, molasses, humic acid, seaweed extract, Aloe vera, cinnamon powder, garlic and cabbage are considered ideal, non-chemical alternatives for rooting of cuttings (Rajan and Singh, 2021). It this regard, Dunsin et al., (2016) indicated that moringa leaf extract gave significantly higher total number of roots, total length of roots and length of the longest root in semi-hardwood cuttings of Parkia biglobosa (African locust bean tree) than pure honey and coconut water treatments, while coconut water was significantly higher in terms of rooted cuttings $\%$ and number of cuttings with callus due to the presence of auxins and cytokinins. Pure honey gave the least records. Likewise, Massoud et al., (2017) reported that the highest means of all vegetative and root growth parameters, as well as chemical constituents of rosemary (Rosmarinus officinalis) were attained by treating terminal cuttings with coconut milk at $75 \%$ rate, except for fresh weight of shoots obtained by treating the terminal cuttings with seaweed extract at $50 \%$ rate and total phenols $\%$ which were obtained from untreated cuttings. In general, using natural products, such as coconut milk, 
seaweed and yeast extracts and bee honey were better than using the chemical growth regulator (IBA) for enhancing rooting, growth and active constituents in rosemary terminal cuttings.

Similar observations were also revealed by Eid et al., (2018) and Gad and Ibrahim (2018) on Picual olive, Gomes et al., (2018) on Passiflora actinia, Al-Habib and Yousif (2020) on Cassia, Ficus, Lantana, Punica and Myrtus, Hameed and Adil (2020) on Melaleuca viminalis, Ibrahim (2020) on Dracaena marginata, Pacholczak and Nowakowska (2020) on ground cover roses Elfrid " Kormuse" and Weisse Immensee "Korweirim" and El Botany and Saleh (2018) who noticed that licorice extract at any concentration caused closely near effect to that of IBA in promoting the rooting of grape rootstock (Dog Ridge) since both treatments increased root number/ cutting, transplant height, leaf number and leaf fresh and dry weights, while seaweed extract enhanced root length and leaf area than IBA did. IBA and licorice $(100 \%)$ recorded the highest IAA values and the lowest ABA values, but slightly improved N, P and K contents. So, licorice and seaweed extracts might be used for rooting grape rootstock (Dog Ridge) as a cheap and clean alternative for IBA. Further, Abdel-Rahman et al., (2020) recommended to treat tip cuttings of Conocarpus erectus with either coconut water for 1 hour or seaweed, extract as drench combined with IBA for enhancing rooting \%, root and shoot growth traits, as well as concentration of endogenous root promoting substances.

However, this study aims to find out the role of both cabbage leaves extract and molasses aqueous solution at various concentrations and immersing times on rooting of Gold Dust croton terminal cuttings rather than IBA chemical hormone.

\section{Materials and Methods}

The current work was conducted under greenhouse conditions at Al-Zohriya Garden, Hort. Res. Inst., Giza, Egypt throughout the two successive seasons of 2018 and 2019 to determine the response of terminal stem cuttings of croton "Gold Dust" to the different immersing time in solution of some natural substances as cheap, safe and more effective alternatives for the synthetic hormone IBA.

Therefore, terminal cuttings were taken from ripe and healthy shoots of Codiaeum variegatum "Gold Dust" plants on mid of July for every season at a length of 12-15 cm, many basal leaves were removed leaving only 4-5 leaves on the cutting. The cuttings were well washed under tap water, then sterilized with a mixture of Topsin (70 \%) and Rizolex (50\%), manufactured by Submitomo Chemical Co., Ltd., Osaka, Japan at the rate of $0.5 \mathrm{~g} / 1$ for each and thereafter immersed for either 15 or 30 minutes in one of the following solutions:

1- Distilled water without any additives as control.

2- Aqueous solution of cabbage leaves extract (Brassica oleracea L. var. Capitata) was prepared by following the method of Cheema and Khaliq (2000) method as follows, 100gm of crumbled fresh cabbage external leaves are taken in a glass jar and then poured on it 1liter of boiled distilled water $(1: 10 \mathrm{w} / \mathrm{v})$ and kept at room temperature for 24 hours, then the solution was filtered through a screen to obtain the purified extract for use as a stock solution (100\%).

3- Aqueous solution of molasses $(100 \%)$. The two previous solutions were diluted with distilled water to prepare the final immersing solution at two levels as follows:

a- $75 \mathrm{ml}$ of either cabbage leaves extract $(100 \%)$ or molasses $(100 \%)+25 \mathrm{ml}$ of distilled water to get $75 \%$ aqueous solution from each.

b- $50 \mathrm{ml}$ of either cabbage leaves extract $(100 \%)$ or molasses $(100 \%)+50 \mathrm{ml}$ of distilled water to get $50 \%$ aqueous solution from each.

4- Aqueous solution of indole-3-butyric acid (IBA, $98 \%$, M.P. 124-125.5 ${ }^{\circ} \mathrm{C}, \mathrm{M} . \mathrm{W} .203 .24$ ) a product from Aldrich Chemical Co. Ltd., Gillingham, Dorest-England at the concentrations of 1500 and $3000 \mathrm{ppm}$, prepared by dissolving 0.375 and $0.75 \mathrm{~g}$ of IBA powder (solubel in water) in $250 \mathrm{ml}$ distilled water for the two abovementioned concentrations, respectively.

Some active components were determined in the two used natural extracts and illustrated in Table (a).

5- Each level of natural extracts (cabbage and molasses) and IBA was combined with the two immersing times to create 12 interaction treatments.

Immediately after termination of immersing time, the treated cuttings and those of control were inserted for 3-4 $\mathrm{cm}$ in 8-cm-diameter plastic pots (one cutting/pot) filled with a mixture of peat moss 
and sand for rooting (2: 1 , by volume). The physical and chemical properties of the peat moss and sand used in the two seasons are shown in Tables (b) and (c), respectively.

Table a: Some active components in cabbage leaves extract and molasses used in the two experimental seasons (2018 and 2019).

Active components in cabbage extract

Active components in molasses

\begin{tabular}{cccccccccc}
\hline $\begin{array}{c}\text { Total amino } \\
\text { acids } \\
(\mathbf{\%})\end{array}$ & $\begin{array}{c}\text { Gibberellic } \\
\text { acid } \\
(\mathbf{m g} / \mathbf{l})\end{array}$ & $\begin{array}{c}\text { ABA } \\
(\mathbf{m g} / \mathbf{l})\end{array}$ & $\begin{array}{c}\text { IBA } \\
(\mathbf{m g} / \mathbf{l})\end{array}$ & $\begin{array}{c}\text { Cytokinin } \\
(\mathbf{m g} / \mathbf{l})\end{array}$ & $\begin{array}{c}\text { Total } \\
\text { amino } \\
\text { acids } \mathbf{( \% )}\end{array}$ & $\begin{array}{c}\text { Gibberellic } \\
\text { acid } \\
(\mathbf{m g} / \mathbf{l})\end{array}$ & $\begin{array}{c}\text { ABA } \\
(\mathbf{m g} / \mathbf{l})\end{array}$ & $\begin{array}{c}\text { IBA } \\
(\mathbf{m g} / \mathbf{l})\end{array}$ & $\begin{array}{c}\text { Cytokinin } \\
(\mathbf{m g} / \mathbf{l})\end{array}$ \\
\hline 0.16 & 185.0 & 19.2 & 14.5 & 25.5 & 0.15 & 370.0 & 30.4 & 190.4 & 102.3 \\
\hline
\end{tabular}

Table b: The physical and chemical properties of the peat moss used in 2018 and 2019 seasons.

\begin{tabular}{lccccc}
\hline Organic matter & $\mathbf{9 0 - 9 5} \%$ & Salinity & $0.3 \mathrm{~g} / 1$ & $\mathbf{M n}$ & $27 \mathrm{ppm}$ \\
\hline Ash & $5-10 \%$ & $\mathbf{N}$ & $1.09 \%$ & $\mathbf{M g}$ & $346 \mathrm{ppm}$ \\
Density (vol. dry) & $85 \mathrm{mg} / 1$ & $\mathbf{P}$ & $0.23 \%$ & $\mathbf{Z n}$ & $41 \mathrm{ppm}$ \\
pH volume & 3.5 & $\mathbf{K}$ & $1.77 \%$ & $\mathbf{C u}$ & $8.8 \mathrm{ppm}$ \\
Water relation capacity & $60-75 \%$ & $\mathbf{F e}$ & $421 \mathrm{ppm}$ & $\mathbf{B}$ & $3.5 \mathrm{ppm}$ \\
\hline
\end{tabular}

Table c: The physical and chemical properties of the sand used in 2018 and 2019 seasons.

\begin{tabular}{|c|c|c|c|c|c|c|c|c|c|c|c|c|c|c|}
\hline \multirow{2}{*}{ Season } & \multicolumn{4}{|c|}{$\begin{array}{c}\text { Particle size distribution } \\
(\%):\end{array}$} & \multirow{2}{*}{ S.P. } & \multirow{2}{*}{$\begin{array}{l}\text { E.C. } \\
(d S / m)\end{array}$} & \multirow{2}{*}{$\mathbf{p H}-$} & \multicolumn{4}{|c|}{$\begin{array}{l}\text { Cations } \\
(\mathrm{meq} / \mathrm{l})\end{array}$} & \multicolumn{3}{|c|}{$\begin{array}{l}\text { Anions } \\
\text { (meq/l) }\end{array}$} \\
\hline & $\begin{array}{c}\text { Coarse } \\
\text { sand }\end{array}$ & $\begin{array}{l}\text { Fine } \\
\text { sand }\end{array}$ & Silt & Clay & & & & $\mathrm{Ca}^{++}$ & $\mathbf{M g}^{++}$ & $\mathbf{N a}^{+}$ & $\mathbf{K}^{+}$ & $\mathrm{HCO}_{3}^{-}$ & $\mathrm{Cl}^{-}$ & $\mathrm{SO}_{4}^{--}$ \\
\hline 2018 & 89.03 & 2.05 & 0.40 & 8.52 & 23.01 & 3.56 & 7.9 & 7.50 & 1.63 & 33.60 & 0.50 & 3.20 & 22.00 & 18.03 \\
\hline 2019 & 84.76 & 6.29 & 1.50 & 7.45 & 21.87 & 3.71 & 7.8 & 19.42 & 8.33 & 7.20 & 0.75 & 1.60 & 7.80 & 26.30 \\
\hline
\end{tabular}

The lower part of pots was buried in the wet soil of greenhouse and the cuttings received all the other agricultural practices whenever needed. The mean of temperatures inside the greenhouse during the course of this study ranged between $26-37{ }^{\circ} \mathrm{C}$ (day/night) $\pm 2^{\circ} \mathrm{C}$, while relative humidity ranged between $65-75 \%$. The layout of the experiment in the two seasons was a complete randomized design in factorial experimental type (Mead et al., 1993) with 3 replicates, as each replicate contained 10 cuttings (one cutting/pot).

Two month later (on September, $7^{\text {th }}$ ), number of the rooted cuttings was counted for each treatment and the rooting percentage was calculated from the following equation: Rooting $\%=$ No. rooted cuttings / total No. cuttings in the treatment x 100. At the same time, the rooted cuttings were transplanted into $14-\mathrm{cm}$-diameter plastic pots containing about $1.2 \mathrm{~kg}$ of the same rooting mixture mentioned before. After other two months (on October, $15^{\text {th }}$ ), the produced transplants were gently lifted and the following data were recorded: transplant length $(\mathrm{cm})$, number of leaves/transplant, the longest root length $(\mathrm{cm})$, number of roots/transplant and top growth and roots fresh and dry weights $(\mathrm{g})$.

In fresh samples, total chlorophyll $(\mathrm{a}+\mathrm{b})$ and carotenoids concentrations, as $\mathrm{mg} / \mathrm{g}$ f.w. were determined according to the method of Sumanta et al., (2014), while in dry ones, the percentages of nitrogen, potassium, phosphorus and total carbohydrates were measured using the methods described by Blacke (1965), Jackson (1973), Herbert et al., (1971) and Wide et al., (1985), successively. Moreover, in methanolic extraction colorless, total indoles, total phenols, total flavonoids and total antioxidants were evaluated by the methods explained by Larsen et al., (1962) modified by Salim et al., (1978), Singleton et al., (1999), Woisky and Salation (1998) and Prieto et al., (1999), successively . 
Data were then tabulated and statistically analyzed using the Assistant Software Program of Silva and Azevedo (2016), which was followed by Duncan's New Multiple Range t-Test (Steel and Torrie, 1980) to compare means of treatments.

\section{Results and Discussion}

\subsection{Effect of rooting treatments, immersing time and their interactions on}

\subsubsection{Rooting percentage and growth of the new formed transplants}

It is obvious from data presented in Table (1) that means of rooting (\%) was greatly improved by the different rooting treatments used in this study with various significant differences as compared to control treatment, which gave only 22.5 and $30.00 \%$ rooting in the first and second seasons, respectively. The highest percent, however was attained by immersing in cabbage extract solution $(75 \%)$ that increased mean values of this character to $98.50 \%$ in the first season and to $99.00 \%$ in the second one, followed by immersing in the same extract solution at $50 \%$ concentration that hastened rooting\% in the $1^{\text {st }}$ season to $97.50 \%$ and in the second one to $98.00 \%$. Immersing in IBA solution at $1500 \mathrm{ppm}$ recorded also good results, as it gave in the 1 st season $97.00 \%$ rooting and in the $2^{\text {nd }}$ one $98.00 \%$.

On the other hand, elongating immersing time from 15 to $30 \mathrm{~min}$. significantly exceeded rooting (\%) from 80.14 to $82.14 \%$ in the $1^{\text {st }}$ season and from 82.14 to $84.29 \%$ in the $2^{\text {nd }}$ one. Thus, combining between immersing in either cabbage extract solution (at any concentration) or IBA solution (at $1500 \mathrm{ppm}$ concentration) and immersing time for $30 \mathrm{~min}$. gave in both seasons the highest rooting percentage at all $(100 \%)$. This may be due to lumping between the positive effects of either cabbage extract or IBA and subjecting the cuttings to longer period of immersing enough to absorb higher amount of rooting promoters.

Table 1: Effect of rooting treatments, immersing time and their interactions on rooting percentage, plant length and number of leaves of the resulted Codiaeum variegatum(Gold Dust) transplants during 2018 and 2019 seasons.

\begin{tabular}{lcccccccccc}
\hline \multicolumn{1}{c}{$\begin{array}{c}\text { Immersing time } \\
\text { (min.) }\end{array}$} & \multicolumn{3}{c}{$\begin{array}{c}\text { Rooting } \\
\text { (\%) }\end{array}$} & \multicolumn{4}{c}{$\begin{array}{c}\text { Transplant length } \\
\text { (cm) }\end{array}$} & \multicolumn{3}{c}{$\begin{array}{c}\text { No. of leaves } \\
\text { / transplant }\end{array}$} \\
\cline { 2 - 11 } Rooting treatments & $\mathbf{1 5}$ min. & $\mathbf{3 0}$ min. & Mean & $\mathbf{1 5}$ min & $\mathbf{3 0}$ min & Mean & $\mathbf{1 5}$ min. & 30 min. & Mean \\
\cline { 2 - 11 } & & & \multicolumn{4}{c}{ First season } & $\mathbf{2 0 1 8}$ \\
Control & $20.00 \mathrm{k}$ & $25.00 \mathrm{j}$ & $22.50 \mathrm{G}$ & $18.03 \mathrm{k}$ & 16.501 & $17.27 \mathrm{G}$ & 10.671 & $14.67 \mathrm{k}$ & $12.67 \mathrm{G}$ \\
IBA (1500 ppm) & $94.00 \mathrm{~d}$ & $100.0 \mathrm{a}$ & $97.00 \mathrm{C}$ & $25.67 \mathrm{f}$ & $27.53 \mathrm{e}$ & $26.60 \mathrm{D}$ & $25.33 \mathrm{f}$ & $25.67 \mathrm{j}$ & $25.50 \mathrm{D}$ \\
IBA (3000 ppm) & $90.00 \mathrm{f}$ & $85.00 \mathrm{~g}$ & $87.50 \mathrm{E}$ & $24.70 \mathrm{~g}$ & $22.60 \mathrm{~h}$ & $23.65 \mathrm{E}$ & $23.33 \mathrm{~g}$ & $21.00 \mathrm{~h}$ & $22.17 \mathrm{E}$ \\
Cabb. ext. (50\%) & $95.00 \mathrm{c}$ & $100.00 \mathrm{a}$ & $97.50 \mathrm{~B}$ & $29.13 \mathrm{c}$ & $32.63 \mathrm{~b}$ & $30.88 \mathrm{~B}$ & $27.33 \mathrm{~d}$ & $29.00 \mathrm{c}$ & $28.17 \mathrm{~B}$ \\
Cabb. ext. (75\%) & $97.00 \mathrm{~b}$ & $100.00 \mathrm{a}$ & $98.50 \mathrm{~A}$ & $32.50 \mathrm{~b}$ & $35.13 \mathrm{a}$ & $33.82 \mathrm{~A}$ & $30.33 \mathrm{~b}$ & $33.67 \mathrm{a}$ & $32.00 \mathrm{~A}$ \\
Molasses (50\%) & $92.00 \mathrm{e}$ & $95.00 \mathrm{c}$ & $93.50 \mathrm{D}$ & $28.33 \mathrm{~d}$ & $29.20 \mathrm{c}$ & $28.77 \mathrm{C}$ & $26.67 \mathrm{e}$ & $27.00 \mathrm{de}$ & $26.83 \mathrm{C}$ \\
Molasses (75\%) & $73.00 \mathrm{~h}$ & $70.00 \mathrm{i}$ & $71.50 \mathrm{~F}$ & $21.50 \mathrm{i}$ & $19.97 \mathrm{j}$ & $20.73 \mathrm{~F}$ & $19.67 \mathrm{i}$ & $17.67 \mathrm{j}$ & $18.67 \mathrm{~F}$ \\
Mean & $80.14 \mathrm{~B}$ & $82.14 \mathrm{~A}$ & & $25.70 \mathrm{~B}$ & $26.22 \mathrm{~A}$ & & $23.33 \mathrm{~B}$ & $24.10 \mathrm{~A}$ & \\
\hline & & & & Second season 2019 & & & \\
Control & $25.00 \mathrm{j}$ & $35.00 \mathrm{i}$ & $30.00 \mathrm{~F}$ & $20.70 \mathrm{i}$ & $23.13 \mathrm{~h}$ & $21.92 \mathrm{~F}$ & $14.33 \mathrm{j}$ & $17.00 \mathrm{i}$ & $15.67 \mathrm{G}$ \\
IBA (1500 ppm) & $96.00 \mathrm{c}$ & $100.00 \mathrm{a}$ & $98.00 \mathrm{~B}$ & $27.60 \mathrm{ef}$ & $28.50 \mathrm{e}$ & $28.05 \mathrm{D}$ & $28.00 \mathrm{e}$ & $29.33 \mathrm{~d}$ & $28.67 \mathrm{D}$ \\
IBA (3000 ppm) & $91.00 \mathrm{e}$ & $88.00 \mathrm{f}$ & $89.50 \mathrm{D}$ & $27.97 \mathrm{e}$ & $26.93 \mathrm{f}$ & $27.45 \mathrm{D}$ & $26.33 \mathrm{f}$ & $26.33 \mathrm{f}$ & $26.33 \mathrm{E}$ \\
Cabb. ext. (50\%) & $96.00 \mathrm{c}$ & $100.00 \mathrm{a}$ & $98.00 \mathrm{~B}$ & $33.37 \mathrm{c}$ & $35.13 \mathrm{~b}$ & $34.25 \mathrm{~B}$ & $31.67 \mathrm{c}$ & $34.33 \mathrm{~b}$ & $33.00 \mathrm{~B}$ \\
Cabb. ext. (75\%) & $98.00 \mathrm{~b}$ & $100.00 \mathrm{a}$ & $99.00 \mathrm{~A}$ & $35.00 \mathrm{~b}$ & $40.33 \mathrm{a}$ & $37.67 \mathrm{~A}$ & $34.00 \mathrm{~b}$ & $36.33 \mathrm{a}$ & $35.17 \mathrm{~A}$ \\
Molasses (50\%) & $94.00 \mathrm{~d}$ & $96.00 \mathrm{c}$ & $95.00 \mathrm{C}$ & $29.97 \mathrm{e}$ & $30.80 \mathrm{~d}$ & $30.38 \mathrm{C}$ & $29.33 \mathrm{~d}$ & $31.33 \mathrm{c}$ & $30.33 \mathrm{C}$ \\
Molasses (75\%) & $75.00 \mathrm{~g}$ & $71.00 \mathrm{~h}$ & $73.00 \mathrm{E}$ & $25.20 \mathrm{~g}$ & $23.67 \mathrm{~h}$ & $24.43 \mathrm{E}$ & $23.33 \mathrm{~g}$ & $18.33 \mathrm{~h}$ & $20.83 \mathrm{~F}$ \\
Mean & $82.14 \mathrm{~B}$ & $84.29 \mathrm{~A}$ & & $28.54 \mathrm{~B}$ & $29.79 \mathrm{~A}$ & & $26.71 \mathrm{~B}$ & $27.57 \mathrm{~A}$ & \\
\hline
\end{tabular}

* Means within a column or row having the same letters are not significantly different according to Duncan's New Multiple Range t-Test at $5 \%$ level. 
Similarly, were those results of the new formed transplants parameters shown in Tables $(1,2$ and 3 ) and Fig. (1), as the mean values of transplant length (cm), number of leaves/transplant, root length $(\mathrm{cm})$, number of roots/transplant, as well as top growth and roots fresh and dry weights $(\mathrm{g})$ were significantly increased in response to the various rooting natural and chemical promoters employed in such trial with the superiority of the aqueous solution of cabbage leaves extract at $75 \%$ concentration treatment, which acquired the utmost high values over all the other treatments in the two seasons, and followed also by the same extract solution of cabbage leaves at $50 \%$ concentration treatment that deservedly occupied the second rank. This may be attributed to that the extract of cabbage leaves contains amino acids $(0.16 \mathrm{mg} / \mathrm{l})$, gibberellic acid $(185.0 \mathrm{ppm})$, indole-3-butyric acid $(145 \mathrm{ppm})$ and cytokinins $(25.5 \mathrm{ppm})$ as shown in Table (a). These phytochemicals are useful in promoting root primordia, cell division and enlargement and nutritive for plants (Lun, 2016).

Table 2: Effect of rooting treatments, immersing time and their interactions on rooting length and number of roots of the resulted Codiaeum variegatum (Gold Dust) transplants during 2018 and 2019 seasons.

\begin{tabular}{lcccccc}
\hline \multirow{2}{*}{ Immersing time (min.) } & \multicolumn{3}{c}{ Root length (cm) } & \multicolumn{3}{c}{ No. of roots/ transplant } \\
\cline { 2 - 7 } Rooting treatments & $\mathbf{1 5}$ min. & $\mathbf{3 0}$ min. & Mean & $\mathbf{1 5}$ min. & $\mathbf{3 0 ~ m i n .}$ & Mean \\
\hline Control & $3.40 \mathrm{k}$ & $5.23 \mathrm{j}$ & $4.32 \mathrm{~F}$ & 5.001 & $8.33 \mathrm{k}$ & $6.67 \mathrm{G}$ \\
IBA (1500 ppm) & $10.97 \mathrm{f}$ & $11.27 \mathrm{ef}$ & $11.12 \mathrm{C}$ & $18.00 \mathrm{f}$ & $21.00 \mathrm{~d}$ & $19.50 \mathrm{D}$ \\
IBA (3000 ppm) & $10.30 \mathrm{~g}$ & $10.23 \mathrm{~g}$ & $10.27 \mathrm{D}$ & $15.00 \mathrm{~g}$ & $13.00 \mathrm{~h}$ & $14.00 \mathrm{E}$ \\
Cabb. ext. (50\%) & $11.60 \mathrm{de}$ & $13.07 \mathrm{c}$ & $12.33 \mathrm{~B}$ & $19.33 \mathrm{e}$ & $24.67 \mathrm{c}$ & $22.00 \mathrm{~B}$ \\
Cabb. ext. (75\%) & $17.43 \mathrm{~b}$ & $19.30 \mathrm{a}$ & $18.37 \mathrm{~A}$ & $26.33 \mathrm{~b}$ & $34.67 \mathrm{a}$ & $30.50 \mathrm{~A}$ \\
Molasses (50\%) & $10.83 \mathrm{f}$ & $11.77 \mathrm{~d}$ & $11.30 \mathrm{C}$ & $17.67 \mathrm{f}$ & $24.33 \mathrm{c}$ & $21.00 \mathrm{C}$ \\
Molasses (75\%) & $7.40 \mathrm{f}$ & $6.37 \mathrm{i}$ & $6.88 \mathrm{E}$ & $12.00 \mathrm{i}$ & $10.00 \mathrm{j}$ & $11.00 \mathrm{~F}$ \\
Mean & $10.28 \mathrm{~B}$ & $11.03 \mathrm{~A}$ & & $16.19 \mathrm{~B}$ & $19.43 \mathrm{~A}$ & \\
\hline & & & Second season 2019 & & \\
Control & $4.00 \mathrm{n}$ & $5.90 \mathrm{~m}$ & $4.95 \mathrm{G}$ & $7.67 \mathrm{k}$ & $10.67 \mathrm{j}$ & $9.17 \mathrm{G}$ \\
IBA (1500 ppm) & $12.00 \mathrm{~h}$ & $14.33 \mathrm{e}$ & $13.17 \mathrm{D}$ & $20.00 \mathrm{f}$ & $25.00 \mathrm{~d}$ & $22.50 \mathrm{D}$ \\
IBA (3000 ppm) & $10.80 \mathrm{i}$ & $10.23 \mathrm{j}$ & $10.52 \mathrm{E}$ & $19.67 \mathrm{f}$ & $16.33 \mathrm{~g}$ & $18.00 \mathrm{E}$ \\
Cabb. ext. (50\%) & $13.50 \mathrm{f}$ & $17.07 \mathrm{c}$ & $15.28 \mathrm{~B}$ & $25.00 \mathrm{~d}$ & $32.67 \mathrm{~b}$ & $28.83 \mathrm{~B}$ \\
Cabb. ext. (75\%) & $20.30 \mathrm{~b}$ & $28.67 \mathrm{a}$ & $24.48 \mathrm{~A}$ & $33.00 \mathrm{~b}$ & $42.00 \mathrm{a}$ & $37.50 \mathrm{~A}$ \\
Molasses (50\%) & $12.50 \mathrm{~g}$ & $15.97 \mathrm{~d}$ & $14.23 \mathrm{C}$ & $21.33 \mathrm{e}$ & $28.00 \mathrm{c}$ & $24.67 \mathrm{C}$ \\
Molasses (75\%) & $9.60 \mathrm{k}$ & 7.731 & $8.67 \mathrm{~F}$ & $15.00 \mathrm{~h}$ & $11.67 \mathrm{i}$ & $13.33 \mathrm{~F}$ \\
Mean & $11.81 \mathrm{~B}$ & $14.27 \mathrm{~A}$ & & $20.24 \mathrm{~B}$ & $23.76 \mathrm{~A}$ & \\
\hline
\end{tabular}

*Means within a column or row having the same letters are not significantly different according to Duncan's New Multiple Range t-Test at $5 \%$ level.

In this regard, Paradikovic et al., (2018) stated that the physiological effects of natural extracts depend on their composition as they contain various organic and mineral compounds which plants can use as metabolites, growth regulators and nutrients. So, they mostly enhance plant vigour, stimulate vegetative growth, improve nutrient acquisition and distribution within the plant, increase antioxidative capacity of plant tissues, contribute to higher stress tolerance and improve flower yield and quality. Abo El-Fadl et al., (2020) indicated that moringa leaves extract showed high nutritional value and had the potential as good source of natural antioxidants which play a great protection role against oxidative stress. Recently, Rajan and Singh (2021) reported that organic rooting extracts of some natural substances, such as: coconut water, willow leaf water, honey, humic acid, seaweed extract, Aloe vera, cabbage outer leaves and cinnamon powder are considered ideal for rooting of cuttings because they reduce the synthetic hormone use (IBA and NAA) and improve the quality and quantity of roots of the rooted cuttings with increasing sustainability of the soil and make it more productive.

Regarding the positive effect of IBA on rooting and initial growth of the new formed transplants, it may be ascribed to the nia gene which encodes nitrate reductase that causes reinduction of nitrate, 
forming the reduced $\mathrm{N}$ needed for lateral root formation and development. Thus, the nia gene is one of the genes expressed during the early stages of root meristem formation (Vuylsteker et al., 1998). Besides, application of auxins (IBA or NAA) may cause a decrease in the level of zeatin-o-glucoside conjngates. Hydrolysis of these conjugates might deliver free zeatin-type compounds which activate the lateral root growth. The aqueous solution of IAA, IBA and NAA promotes lateral root number and elongates the primary root axis (Taylor and Sladen, 1998). In addition, Rajan and Singh (2021) suggested that IBA and NAA enhance the initiation of root primordia and growth through cell multiplication. Such hormones support mobilization of sugars and nutrients by the hydrolysis of starch at the base of the cuttings.

As noticed before in case of rooting \%, it was also noticed that protraction immersing time from $15 \mathrm{~min}$. to 30 minutes significantly raised the mean values of different vegetative and root growth traits of the resulted transplants (Tables, 1,2 and 3) due to giving the cuttings the proper chance to absorb enough volume from rooting solution that contains metabolites, growth regulator-like substances and nutrients necessary for good growth (Paradikovic et al., 2018). So, interacting between soaking in cabbage extract solution at $75 \%$ concentration and immersing time of 30 minutes registered the highest growth values relative to all the other interactions in both seasons, scoring the tallest plant, longest root, highest number of leaves and roots/transplant and the heaviest fresh and dry weights of top growth and roots. Furthermore, combining between immersing the cuttings in the same aforenamed solution at the same concentration and immersing time for $15 \mathrm{~min}$. came in the second place. Also, a combination of submersing in cabbage extract solution at $50 \%$ concentration for 30 minutes recorded better results in some growth traits. This may indicate the importance of connecting between more factors in the research trials, where each factor hastened the other one, as remarked in this study.

Table 3: Effect of rooting treatments, immersing time and their interactions on top growth and roots fresh and dry weights of the resulted Codiaeum variegatum (Gold Dust) transplants during 2018 and 2019 seasons.

\begin{tabular}{|c|c|c|c|c|c|c|c|c|c|c|c|c|}
\hline \multirow{3}{*}{$\begin{array}{r}\text { Immersing time } \\
\text { (min.) }\end{array}$} & \multicolumn{6}{|c|}{ Top growth } & \multicolumn{6}{|c|}{ Roots } \\
\hline & \multicolumn{3}{|c|}{ Fresh weight (g) } & \multicolumn{3}{|c|}{ Dry weight (g) } & \multicolumn{3}{|c|}{ Fresh weight (g) } & \multicolumn{3}{|c|}{ Dry weight (g) } \\
\hline & $\begin{array}{c}15 \\
\text { min. }\end{array}$ & $\begin{array}{c}\text { 30 } \\
\text { min. }\end{array}$ & Mean & $\begin{array}{c}15 \\
\text { min. }\end{array}$ & $\begin{array}{c}\text { 30 } \\
\text { min. }\end{array}$ & Mean & $\begin{array}{c}15 \\
\text { min. }\end{array}$ & $\begin{array}{c}30 \\
\text { min. }\end{array}$ & Mean & $\begin{array}{c}15 \\
\text { min. }\end{array}$ & $\begin{array}{c}30 \\
\text { min. }\end{array}$ & Mean \\
\hline Rooting treatments & \multicolumn{12}{|c|}{ First season : 2018} \\
\hline Control & $8.29 \mathrm{j}$ & $9.35 \mathrm{i}$ & $8.82 \mathrm{G}$ & $1.86 \mathrm{~g}$ & $1.94 \mathrm{~g}$ & $1.90 \mathrm{~F}$ & $0.20 \mathrm{i}$ & $0.49 \mathrm{~g}-\mathrm{i}$ & i $0.35 \mathrm{E}$ & $0.11 \mathrm{i}$ & $0.24 \mathrm{~g}-\mathrm{i}$ & $0.18 \mathrm{E}$ \\
\hline IBA (1500 ppm) & $12.62 \mathrm{f}$ & $13.03 \mathrm{e}$ & $12.82 \mathrm{D}$ & $2.70 \mathrm{de}$ & $2.76 \mathrm{~d}$ & $2.73 \mathrm{D}$ & $0.75 \mathrm{f}-\mathrm{h}$ & $0.86 \mathrm{fg}$ & $0.80 \mathrm{D}$ & $0.27 \mathrm{~g}$ & $0.35 \mathrm{fg}$ & $0.31 \mathrm{D}$ \\
\hline IBA (3000 ppm) & $12.51 \mathrm{f}$ & $11.72 \mathrm{~g}$ & $12.11 \mathrm{E}$ & $2.52 \mathrm{e}$ & $2.24 \mathrm{f}$ & $2.38 \mathrm{E}$ & $0.59 \mathrm{~g}-\mathrm{i}$ & $0.38 \mathrm{hi}$ & $0.49 \mathrm{E}($ & $0.26 \mathrm{gh}$ & $0.14 \mathrm{hi}$ & $0.20 \mathrm{E}$ \\
\hline Cabb. ext. (50\%) & $15.23 \mathrm{c}$ & $17.64 b$ & $16.44 \mathrm{~B}$ & $3.36 \mathrm{c}$ & $3.49 \mathrm{bc}$ & $3.42 \mathrm{~B}$ & $1.79 \mathrm{~cd}$ & $2.18 \mathrm{bc}$ & $1.99 \mathrm{~B}$ & $0.73 d$ & $0.87 \mathrm{c}$ & $0.80 \mathrm{~B}$ \\
\hline Cabb. ext. (75\%) & $17.49 \mathrm{~b}$ & $18.93 \mathrm{a}$ & $18.21 \mathrm{~A}$ & $3.71 \mathrm{~b}$ & $4.36 \mathrm{a}$ & $4.04 \mathrm{~A}$ & $2.49 \mathrm{~b}$ & $3.53 \mathrm{a}$ & $3.01 \mathrm{~A}$ & $1.28 \mathrm{~b}$ & $1.42 \mathrm{a}$ & $1.35 \mathrm{~A}$ \\
\hline Molasses (50\%) & $13.46 \mathrm{~h}$ & $15.13 \mathrm{c}$ & $14.30 \mathrm{C}$ & $2.91 \mathrm{~d}$ & $3.28 \mathrm{c}$ & $3.10 \mathrm{C}$ & $1.07 \mathrm{ef}$ & $1.39 \mathrm{de}$ & $1.23 \mathrm{C}$ & $0.42 \mathrm{ef}$ & $0.53 \mathrm{e}$ & $0.47 \mathrm{C}$ \\
\hline Molasses (75\%) & $10.56 \mathrm{~h}$ & $9.56 \mathrm{i}$ & $10.06 \mathrm{~F}$ & $1.56 \mathrm{~h}$ & $1.32 \mathrm{i}$ & $1.44 \mathrm{G}$ & $0.35 \mathrm{hi}$ & $0.26 \mathrm{i}$ & $0.31 \mathrm{E}$ & $0.15 \mathrm{hi}$ & $0.12 \mathrm{i}$ & $0.13 \mathrm{E}$ \\
\hline \multirow[t]{2}{*}{ Mean } & $12.88 \mathrm{~B}$ & $13.62 \mathrm{~A}$ & & $2.66 \mathrm{~B}$ & $2.77 \mathrm{~A}$ & & $1.03 \mathrm{~B}$ & $1.30 \mathrm{~A}$ & & $0.46 \mathrm{~B}$ & $0.52 \mathrm{~A}$ & \\
\hline & \multicolumn{12}{|c|}{ Second season :2019 } \\
\hline Control & $10.47 \mathrm{~m}$ & 11.311 & $10.89 \mathrm{G}$ & $2.03 \mathrm{i}$ & $2.12 \mathrm{hi}$ & $2.08 \mathrm{~F}$ & $0.54 \mathrm{j}$ & $0.90 \mathrm{j}$ & $0.72 \mathrm{~F}$ & $0.27 \mathrm{~h}$ & $0.32 \mathrm{~h}$ & $0.30 \mathrm{~F}$ \\
\hline IBA (1500 ppm) & $14.78 \mathrm{~h}$ & $15.83 \mathrm{f}$ & $15.31 \mathrm{D}$ & $2.97 \mathrm{ef}$ & $3.21 \mathrm{e}$ & $3.09 \mathrm{D}$ & $1.90 \mathrm{fg}$ & $2.42 \mathrm{de}$ & $2.16 \mathrm{D}$ & $0.76 \mathrm{f}$ & $0.95 \mathrm{de}$ & $0.86 \mathrm{C}$ \\
\hline IBA (3000 ppm) & $14.13 \mathrm{i}$ & $13.35 \mathrm{j}$ & $13.74 \mathrm{E}$ & $2.49 \mathrm{~g}$ & $3.20 \mathrm{hi}$ & $2.35 \mathrm{E}$ & $1.71 \mathrm{gh}$ & $1.37 \mathrm{hi}$ & $1.54 \mathrm{E}$ & $0.74 \mathrm{f}$ & $0.57 \mathrm{~g}$ & $0.66 \mathrm{D}$ \\
\hline Cabb. ext. (50\%) & $18.17 \mathrm{~d}$ & $19.65 \mathrm{c}$ & 18.91B & $3.72 \mathrm{~d}$ & $4.68 \mathrm{c}$ & $4.20 \mathrm{~B}$ & $3.15 \mathrm{c}$ & $3.85 \mathrm{~b}$ & $3.50 \mathrm{~B}$ & $1.04 \mathrm{~d}$ & $1.58 \mathrm{c}$ & $1.31 \mathrm{~B}$ \\
\hline Cabb. ext. (75\%) & $21.11 \mathrm{~b}$ & $24.64 \mathrm{a}$ & $22.88 \mathrm{~A}$ & $5.28 \mathrm{~b}$ & $7.53 \mathrm{a}$ & $6.40 \mathrm{~A}$ & $3.75 b$ & $4.52 \mathrm{a}$ & $4.13 \mathrm{~A}$ & $1.94 \mathrm{~b}$ & $2.89 \mathrm{a}$ & $2.42 \mathrm{~A}$ \\
\hline Molasses (50\%) & $15.31 \mathrm{~g}$ & $16.74 \mathrm{e}$ & $16.03 \mathrm{C}$ & $2.88 \mathrm{f}$ & $3.71 \mathrm{~d}$ & $3.30 \mathrm{C}$ & $2.20 \mathrm{ef}$ & $2.77 \mathrm{~cd}$ & $2.49 \mathrm{C}$ & $0.84 \mathrm{ef}$ & $1.02 \mathrm{~d}$ & $0.93 \mathrm{C}$ \\
\hline Molasses (75\%) & $12.18 \mathrm{k}$ & $11.93 \mathrm{k}$ & $12.05 \mathrm{~F}$ & $2.39 \mathrm{gh}$ & $2.19 \mathrm{hi}$ & $2.29 \mathrm{E}$ & 1.47hi & $1.29 \mathrm{i}$ & $1.38 \mathrm{E}$ & $0.58 \mathrm{~g}$ & $0.41 \mathrm{~h}$ & $0.50 \mathrm{E}$ \\
\hline Mean & $15.16 \mathrm{~B}$ & $16.21 \mathrm{~A}$ & & $3.11 \mathrm{~B}$ & $3.66 \mathrm{~A}$ & & $2.10 \mathrm{~B}$ & $2.44 \mathrm{~A}$ & & $0.88 \mathrm{~B}$ & $1.11 \mathrm{~A}$ & \\
\hline
\end{tabular}

* Means within a column or row having the same letters are not significantly different according to Duncan's New Multiple Range t-Test at $5 \%$ level. 

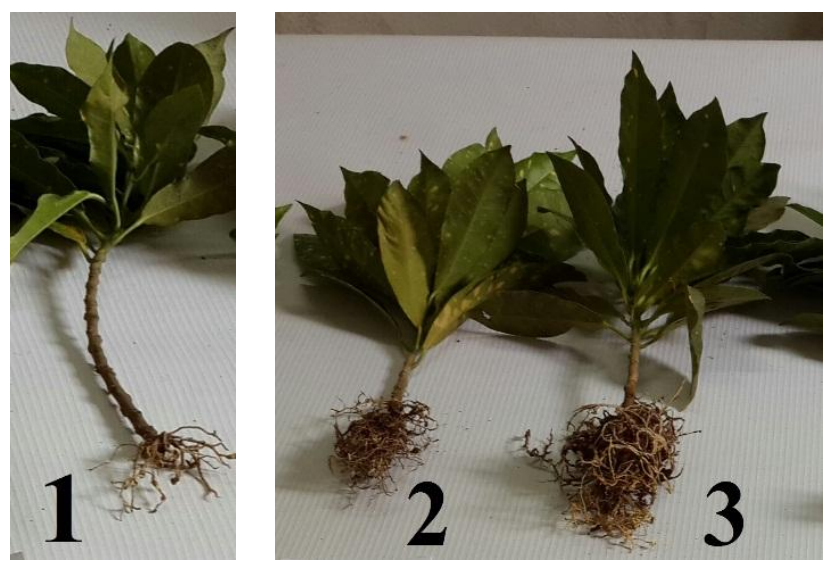

Fig. 1: Effect of the natural extracts treatments on rooting of the terminal stem cuttings of Codiaeum variegatum. Treatments from left to right: 1: control for $30 \mathrm{~min}$. 2: IBA at 1500ppm for 30 min. 3: Cabbage leaves extract at $75 \%$ level for $30 \mathrm{~min}$.

The previous results are in accordance with those revealed by Baldotto et al., (2012) who concluded that application of either IBA $(597 \mathrm{mg} / \mathrm{l})$ or HA $(14 \mathrm{mmol} / \mathrm{l})$ accelerated rooting of Codiaeum variegatum cuttings and raised root dry matter to the maximum. Goda et al., (2018) found that treating Phytolacca dioica cuttings with IBA at 4000ppm + NAA at 4000ppm gave the highest rooting\% and root length. On rosemary (Rosmarinus officinalis), Massoud et al., (2017) declared that treating terminal cuttings with coconut milk at the rate of $75 \%$ attained the highest rooting $\%$, root number and length with the greatest means of all vegetative growth parameters of the new transplants, except for shoot fresh weight that was obtained when terminal cuttings treated with seaweed extract at $50 \%$ rate. Using natural products such as coconut milk, seaweed extract, yeast extract and bee honey recorded, in general better rooting and growth results than IBA synthetic hormone. Similarly, Gomes et al., (2018) found that immersing of Possiflora actinia stem cuttings in brown seaweed extract at a concentration of $40 \%$ increased rooting $\%$ to an average of $51.3 \%$ plus $15.6 \%$ increase in leaf retention, and that facilitate the species propagation. For rooting the medium cuttings of Melaleuca viminalis. Hameed and Adel (2020) mentioned that the rooting solution of 750ppm IBA $+750 \mathrm{ppm}$ NAA $+20 \mathrm{ppm}$ cinnamon extract acquired the highest rooting rate, length of vegetative growth and number of leaves when accompanied with wounding.

\subsubsection{Chemical composition of the leaves:}

An identical response to that of rooting percentage and vegetative and root growth characters of the resulted transplants was also obtained concerning the most chemical constituents concentrations determined in the leaves (Tables, 4, 5, and 6) where concentrations of total chlorophyll $(\mathrm{a}+\mathrm{b})$ and carotenoids (mg/g f.w.), the percentages of nitrogen, potassium, phosphorus and total carbohydrates, as well as total antioxidants and total indoles concentrations $(\mathrm{mg} / 100 \mathrm{~g} \mathrm{~d}$. w.) were maximum by immersing in cabbage leaves extract solution at $75 \%$ concentration. Also, elongating the submersion time from 15 to $30 \mathrm{~min}$. significantly increased the mean values of these constituents in most cases of the two seasons. Therefore, the combining between soaking the cuttings in solution of cabbage leaves extract (75\% concentration) and immersing time of 30 minutes attained the utmost high concentrations of such chemical components over all individual and other combined treatments used in this study. This may be reasonable because the cabbage outer leaves extract is potential source of phytochemicals which could be useful ingredients for natural and effective nutrition method of plants (Lun, 2016). In this respect, Paradikovic et al., (2018) stated that natural extracts of some plants have beneficial effects on plant growth and development, as they contain various organic and mineral compounds which plants can use as metabolites, growth regulators and nutrients. Thus, they can improve nutrient uptaking and distribution within the plants. Also, AboEl-FAdl et al., (2020) concluded that moringa leaf extract showed a certain nutritional value and could provide healthy benefits to plants. Besides, Rajan and Singh (2021) proved that use of natural rooting extracts derived from coconut milk, willow leaf water, honey, humic acid, cabbage leaves, seaweed extract, Aloe vera, garlic, yeast and cinnamon powder are 
ideal for rooting of cuttings and initial growth of the new formed transplants due to that they contain high amounts of growth regulator-like substances and minerals.

The results mentioned before can be supported by those detected by El-Fouly et al., (2009) on Ficus deltoidea, El-Sayed et al., (2010 a) on Hibiscus rosa-sinensis, El-Sayed et al., (2010 b) on Bougainvillea glabra, Massoud et al., (2017) on rosemary and Abdel-Rahman (2020) who revealed that IBA at $100 \mathrm{ppm}$ recorded the highest endogenous contents of phenols, IAA and the lowest abscisic acid (ABA) content in tip cuttings of Conocarpus erectus planted in vermiculite substrate. Ibrahim (2020) affirmed that seaweed extract at $2 \mathrm{ml} / \mathrm{l}$ alone or combined with IBA $(300 \mathrm{ppm})$ and phloroglucinol $(300 \mathrm{ppm})$ increased total carbohydrates, but reduced total phenolics in the root zone tissues of Dracaena marginata air layers. Likewise, Pacholczak, and Nowakowska, (2020) reported that spraying foliage of Elfrid "Kormuse" and Weisse Immensee "Korweirim" roses cuttings with the commercial Goteo biostimulator (contains $1 \%$ IBA + natural extracts) significantly increased chlorophyll $(\mathrm{a}+\mathrm{b})$ and total soluble sugars in the cuttings, but the levels of free amino acids and polyphenolic acids were decreased.

Table 4: Effect of rooting treatments, immersing time and their interactions on pigments concentration in the leaves of the resulted Codiaeum variegatum (Gold Dust) transplants during 2018 and 2019 seasons.

\begin{tabular}{lcccccc}
\hline \multicolumn{1}{c}{ Immersing time(min.) } & \multicolumn{3}{c}{$\begin{array}{c}\text { Total chlorophyll } \\
\text { (mg/g f. w.) }\end{array}$} & \multicolumn{3}{c}{$\begin{array}{c}\text { Carotenoids } \\
\text { (mg/g f. w.) }\end{array}$} \\
\cline { 2 - 7 } Rooting treatments & $\mathbf{1 5}$ min. & $\mathbf{3 0}$ min. & Mean & $\mathbf{1 5}$ min. & $\mathbf{3 0 ~ m i n}$. & Mean \\
& $0.473 \mathrm{j}$ & $0.592 \mathrm{i}$ & $0.532 \mathrm{G}$ & 0.0271 & $0.051 \mathrm{k}$ & $0.039 \mathrm{G}$ \\
Control & $1.261 \mathrm{e}$ & $1.293 \mathrm{de}$ & $1.277 \mathrm{D}$ & $0.420 \mathrm{fg}$ & $0.436 \mathrm{ef}$ & $0.428 \mathrm{D}$ \\
IBA (1500 ppm) & $1.195 \mathrm{f}$ & $1.107 \mathrm{~g}$ & $1.151 \mathrm{E}$ & $0.411 \mathrm{gh}$ & $0.388 \mathrm{~h}$ & $0.400 \mathrm{E}$ \\
IBA (3000 ppm) & $1.385 \mathrm{c}$ & $1.495 \mathrm{~b}$ & $1.440 \mathrm{~B}$ & $0.496 \mathrm{~d}$ & $0.530 \mathrm{c}$ & $0.513 \mathrm{~B}$ \\
Cabb. ext. (50\%) & $1.544 \mathrm{~b}$ & $1.789 \mathrm{a}$ & $1.667 \mathrm{~A}$ & $0.572 \mathrm{~b}$ & $0.636 \mathrm{a}$ & $0.604 \mathrm{~A}$ \\
Cabb. ext. (75\%) & $1.342 \mathrm{~cd}$ & $1.380 \mathrm{c}$ & $1.361 \mathrm{C}$ & $0.450 \mathrm{e}$ & $0.487 \mathrm{~d}$ & $0.469 \mathrm{C}$ \\
Molasses (50\%) & $1.091 \mathrm{~g}$ & $0.929 \mathrm{~h}$ & $1.010 \mathrm{~F}$ & $0.352 \mathrm{i}$ & $0.244 \mathrm{j}$ & $0.298 \mathrm{~F}$ \\
Molasses (75\%) & $1.184 \mathrm{~B}$ & $1.226 \mathrm{~A}$ & & $0.390 \mathrm{~A}$ & $0.396 \mathrm{~A}$ & \\
Mean & & & Second season 2019 & & \\
\hline & $0.518 \mathrm{i}$ & $0.636 \mathrm{~h}$ & $0.577 \mathrm{G}$ & 0.0741 & $0.104 \mathrm{k}$ & $0.089 \mathrm{G}$ \\
Control & $1.296 \mathrm{e}$ & $1.336 \mathrm{de}$ & $1.316 \mathrm{D}$ & $0.439 \mathrm{~g}$ & $0.455 \mathrm{fg}$ & $0.447 \mathrm{D}$ \\
IBA (1500 ppm) & $1.287 \mathrm{e}$ & $1.133 \mathrm{f}$ & $1.210 \mathrm{E}$ & $0.423 \mathrm{~h}$ & $0.402 \mathrm{i}$ & $0.412 \mathrm{E}$ \\
IBA (3000 ppm) & $1.542 \mathrm{c}$ & $1.662 \mathrm{~b}$ & $1.602 \mathrm{~B}$ & $0.531 \mathrm{~d}$ & $0.656 \mathrm{c}$ & $0.593 \mathrm{~B}$ \\
Cabb. ext. (50\%) & $1.715 \mathrm{~b}$ & $1.921 \mathrm{a}$ & $1.818 \mathrm{~A}$ & $0.688 \mathrm{~b}$ & $0.870 \mathrm{a}$ & $0.779 \mathrm{~A}$ \\
Cabb. ext. (75\%) & $1.348 \mathrm{de}$ & $1.389 \mathrm{~d}$ & $1.369 \mathrm{C}$ & $0.469 \mathrm{f}$ & $0.494 \mathrm{e}$ & $0.482 \mathrm{C}$ \\
Molasses (50\%) & $1.126 \mathrm{f}$ & $0.980 \mathrm{~g}$ & $1.053 \mathrm{~F}$ & $0.386 \mathrm{i}$ & $0.313 \mathrm{j}$ & $0.350 \mathrm{~F}$ \\
Molasses (75\%) & $1.262 \mathrm{~B}$ & $1.294 \mathrm{~A}$ & & $0.430 \mathrm{~B}$ & $0.471 \mathrm{~A}$ & \\
Mean & & & & &
\end{tabular}

*Means within a column or row having the same letters are not significantly different according to Duncan's New Multiple Range t-Test at $5 \%$ level. 
Table 5: Effect of rooting treatments, immersing time and their interactions on nitrogen, total carbohydrates (\%) phosphorus and potassium concentration (average of both seasons) in the leaves of the resulted Codiaeum variegatum (Gold Dust) transplants.

\begin{tabular}{|c|c|c|c|c|c|c|c|c|c|c|c|c|}
\hline \multirow{2}{*}{$\begin{array}{l}\text { Immersing time } \\
\text { (min.) } \\
\text { Rooting } \\
\text { treatments }\end{array}$} & \multicolumn{3}{|c|}{$\mathbf{N}(\%)$} & \multicolumn{3}{|c|}{$\mathbf{P}(\%)$} & \multicolumn{3}{|c|}{ K (\%) } & \multicolumn{3}{|c|}{ Total carbohydrates (\%) } \\
\hline & 15 min. & $30 \mathrm{~min}$. & Mean & 15 min. & $30 \mathrm{~min}$. & Mean & 15 min. & $30 \mathrm{~min}$. & Mean & 15 min. & $30 \mathrm{~min}$. & Mean \\
\hline Control & $1.01 \mathrm{j}$ & $1.44 \mathrm{i}$ & $1.23 \mathrm{G}$ & $0.219 \mathrm{j}$ & $0.261 \mathrm{i}$ & $0.240 \mathrm{G}$ & $1.36 \mathrm{i}$ & $1.95 \mathrm{~h}$ & $1.66 \mathrm{E}$ & $9.20 \mathrm{k}$ & $10.79 j$ & $10.00 \mathrm{G}$ \\
\hline IBA (1500 ppm) & $2.16 \mathrm{f}$ & $2.24 \mathrm{e}$ & $2.20 \mathrm{D}$ & $0.386 \mathrm{~g}$ & $0.480 \mathrm{f}$ & $0.433 \mathrm{D}$ & $2.68 \mathrm{~d}-\mathrm{f}$ & $2.74 \mathrm{c}-\mathrm{e}$ & $2.71 \mathrm{C}$ & $17.25 \mathrm{f}$ & $17.99 \mathrm{ef}$ & $17.62 \mathrm{D}$ \\
\hline IBA (3000 ppm) & $2.12 \mathrm{f}$ & $2.00 \mathrm{~g}$ & $2.06 \mathrm{E}$ & $0.369 \mathrm{~g}$ & $0.333 \mathrm{~h}$ & $0.451 \mathrm{E}$ & $2.51 \mathrm{e}-\mathrm{g}$ & $2.39 \mathrm{~g}$ & $2.45 \mathrm{D}$ & $15.69 \mathrm{~g}$ & $15.31 \mathrm{gh}$ & $15.50 \mathrm{E}$ \\
\hline Cabb. ext. $(50 \%)$ & $2.47 \mathrm{~d}$ & $2.92 b$ & $2.70 \mathrm{~B}$ & $0.767 d$ & $0.865 \mathrm{c}$ & $0.816 \mathrm{~B}$ & $2.82 \mathrm{~b}-\mathrm{d}$ & $2.97 \mathrm{bc}$ & $2.90 \mathrm{~B}$ & $19.48 \mathrm{~d}$ & $21.03 \mathrm{c}$ & $20.26 \mathrm{~B}$ \\
\hline Cabb. ext. (75\%) & $2.96 \mathrm{~b}$ & $3.20 \mathrm{a}$ & $3.08 \mathrm{~A}$ & $1.490 \mathrm{~b}$ & $1.860 \mathrm{a}$ & $1.675 \mathrm{~A}$ & $3.03 \mathrm{~b}$ & $3.34 \mathrm{a}$ & $3.19 \mathrm{~A}$ & $22.78 b$ & $24.38 \mathrm{a}$ & $23.58 \mathrm{~A}$ \\
\hline Molasses (50\%) & $2.45 \mathrm{~d}$ & $2.66 \mathrm{c}$ & $2.55 \mathrm{C}$ & $0.660 \mathrm{e}$ & $0.690 \mathrm{e}$ & $0.675 \mathrm{C}$ & $2.59 \mathrm{~d}-\mathrm{g}$ & $2.76 \mathrm{~b}-\mathrm{e}$ & $2.68 \mathrm{C}$ & $18.18 \mathrm{ef}$ & $19.08 \mathrm{de}$ & $18.63 \mathrm{C}$ \\
\hline Molasses (75\%) & $2.03 \mathrm{~g}$ & $1.87 \mathrm{~h}$ & $1.95 \mathrm{~F}$ & $0.320 \mathrm{~h}$ & $0.312 \mathrm{~h}$ & $0.316 \mathrm{~F}$ & $2.43 \mathrm{fg}$ & $2.12 \mathrm{~h}$ & $2.28 \mathrm{D}$ & 14.40hi & $13.63 \mathrm{i}$ & $14.02 \mathrm{~F}$ \\
\hline Mean & $2.17 \mathrm{~B}$ & $2.33 \mathrm{~A}$ & & $0.602 \mathrm{~B}$ & $0.686 \mathrm{~A}$ & & $2.49 \mathrm{~B}$ & $2.61 \mathrm{~A}$ & & $16.71 \mathrm{~B}$ & $17.46 \mathrm{~A}$ & \\
\hline
\end{tabular}

* Means within a column or row having the same letters are not significantly different according to Duncan's New Multiple Range t-Test at $5 \%$ level.

Table 6: Effect of rooting treatments, immersing time and their interactions on concentration of some constituents in the leaves of Codiaeum variegatum (Gold Dust) transplants as average of both seasons.

\begin{tabular}{|c|c|c|c|c|c|c|c|c|c|c|c|c|}
\hline \multirow{2}{*}{$\begin{array}{r}\text { Immersing } \\
\text { time(min.) } \\
\text { Rooting treatments }\end{array}$} & \multicolumn{3}{|c|}{$\begin{array}{c}\text { Total phenols } \\
(\mathrm{mg} / \mathbf{1 0 0 g} \text { d.w.) } \\
\end{array}$} & \multicolumn{3}{|c|}{$\begin{array}{l}\text { Total indoles } \\
(\mathrm{mg} / \mathbf{1 0 0 g} \text { d.w.) }\end{array}$} & \multicolumn{3}{|c|}{$\begin{array}{l}\text { Total flavonoids } \\
\text { (mg/100g d.w.) }\end{array}$} & \multicolumn{3}{|c|}{$\begin{array}{c}\text { Total antioxidant } \\
(\mathrm{mg} / 100 \mathrm{~g} \text { d.w. })\end{array}$} \\
\hline & 15 min. & 30 min. & Mean & 15 min. & $30 \mathrm{~min}$. & Mean & 15 min. & 30 min. & Mean & $\begin{array}{c}15 \\
\text { min. }\end{array}$ & $\begin{array}{c}30 \\
\text { min. }\end{array}$ & Mean \\
\hline Control & $988.5 \mathrm{a}$ & $724.3 b$ & $856.4 \mathrm{~A}$ & $21.95 \mathrm{k}$ & $32.09 \mathrm{j}$ & $27.02 \mathrm{G}$ & $162.28 \mathrm{a}$ & $137.18 b$ & $149.73 \mathrm{~A}$ & $751.9 n$ & $845.3 \mathrm{~m}$ & $798.6 \mathrm{G}$ \\
\hline IBA (1500 ppm) & $285.2 \mathrm{~g}$ & $230.1 \mathrm{~h}$ & $252.6 \mathrm{D}$ & $69.15 \mathrm{f}$ & $85.50 \mathrm{e}$ & 77.33D & $84.21 \mathrm{~g}$ & $79.60 \mathrm{~h}$ & 81.90D & $1471.5 \mathrm{~g}$ & $1585.4 \mathrm{f}$ & $1528.5 \mathrm{D}$ \\
\hline IBA (3000 ppm) & $382.3 \mathrm{f}$ & $459.3 \mathrm{e}$ & $420.8 \mathrm{C}$ & $63.20 \mathrm{~g}$ & $53.72 \mathrm{~h}$ & $58.46 \mathrm{E}$ & $90.23 \mathrm{f}$ & $105.90 \mathrm{e}$ & $97.07 \mathrm{C}$ & $1336.8 \mathrm{i}$ & $1207.6 \mathrm{j}$ & $1272.2 \mathrm{E}$ \\
\hline Cabb. Ext. (50\%) & $160.1 \mathrm{k}$ & 134.51 & $147.3 \mathrm{~F}$ & $117.40 \mathrm{c}$ & $138.53 b$ & $127.96 \mathrm{~B}$ & $58.17 \mathrm{k}$ & 50.601 & $54.38 \mathrm{~F}$ & $1936.0 \mathrm{~d}$ & $2070.1 \mathrm{c}$ & 2003.1B \\
\hline Cabb. Ext. (75\%) & $113.9 \mathrm{~m}$ & $87.70 \mathrm{n}$ & $100.8 \mathrm{G}$ & $139.11 b$ & $200.55 a$ & $169.83 \mathrm{~A}$ & $41.32 \mathrm{~m}$ & $31.94 n$ & $36.63 \mathrm{G}$ & $2441.0 \mathrm{~b}$ & $2813.2 \mathrm{a}$ & $2627.1 \mathrm{~A}$ \\
\hline Molasses (50\%) & $206.9 \mathrm{i}$ & $189.0 \mathrm{j}$ & $198.0 \mathrm{E}$ & $93.92 d$ & $113.09 \mathrm{c}$ & $103.51 \mathrm{C}$ & $72.57 \mathrm{i}$ & $61.88 \mathrm{j}$ & $67.22 \mathrm{E}$ & $1386.8 \mathrm{~h}$ & $1806.3 \mathrm{e}$ & $1596.5 \mathrm{C}$ \\
\hline Molasses $(75 \%)$ & $591.0 \mathrm{~d}$ & $690.9 \mathrm{c}$ & $641.0 \mathrm{~B}$ & $42.06 \mathrm{i}$ & $37.67 i$ & $39.87 \mathrm{~F}$ & $113.99 \mathrm{~d}$ & $128.27 \mathrm{c}$ & 121.13B & $1142.4 \mathrm{k}$ & 1075.71 & $1109.0 \mathrm{~F}$ \\
\hline Mean & $388.3 \mathrm{~A}$ & 359.4B & & $78.11 \mathrm{~B}$ & $97.45 \mathrm{~A}$ & & 88.97A & 85.05B & & 1495.2B & $1629.1 \mathrm{~A}$ & \\
\hline
\end{tabular}

* Means within a column or row having the same letters are not significantly different according to Duncan's New Multiple Range t-Test at $5 \%$ level. 


\section{References}

Abdel-Rahman, S.S.A., 2020. Influence of rooting media and indole-3-butyric acid (IBA) concentration on rooting and growth of different types of Conocarpus erectus L. stem cuttings. Scientific J. Flowers \& Ornam. Plants, 7(3):199-219.

Abdel-Rahman, S.S.A., E.Y. Abdul-Hafeez, and A.M.M. Saleh, 2020. Improving rooting and growth of Conocarpus erectus stem cutting using indole- 3-butyric acid (IBA) and some biostimulants. Scientific J. Flowers \& Ornamental Plants, 7(2):109-129.

Abo El-Fadl, S.R., A. Osman, A.M. Al-Zohairy, Dahab, A. Abeer and A. AboEl-Kheir, Zakia, 2020. Assessment of total phenolic, flavonoid content, antioxidant potential and HPLC profile of three Moringa species leaf extracts. Scientific J. Flowers \& Ornam. Plants, 7(1):53-70.

Al- Habib, A.A.S. andA.M. Yousif, , 2020. Evaluation the activity of some medicinel plant extracts as root promoters. AIP Conference Proceedings, 2213(1): 453-463.

Araya, H.T., 2005. Seed germination and vegetative propagation of bush tea (Athrixia phylicoides). M.Sc. Thesis, Univ. Pretoria, Pretoria, South Africa.

Baldotto, L.E., M.A. Baldotto, R.R. Soares, H.E. Martinez, and V.H. Adventitious, 2012. Rooting of croton and Hibiscus cuttings in response to indolebutyric acid and humic acid. Rev. Ceries, Viçosa, 59(4):476- 483.

Balestri, E., F. Vallerini, A. Castelli, and C. Lardicci, 2012. Application of plant growth regulators, a simple technique for improving the establishment auccess of plant cuttings in Coastal dune restoration. Estuarine, Coastal and Shelf Science, 99 (1):74-84.

Bester, C., 2013. A model for commercialization of honeybush tea, an indigenous crop. Acta Hort., 1007:889-894.

Bijekar, S.R. and M.C. Gayatri, 2014. Phytochemical profile of Codiaeum variegatum (L.) B1. International Journal of Pharmacology and Pharmaceutical Sciences, 2 (3): 22-31

Blacke, C.A., 1965. Methods of Soil Analysis. Part I and II. Amer. Soc. Agron. in Pupl. Madison. Wise U.S.A.

Deshmukh, S.D. and M.N. Borle, 1975. Studies on the insecticidal properties of indigenous plant products. Ind. J. Ent., 37(1):11-18.

Dunsin, O., G. Ajiboye, and T. Adeyemo, 2016. Effect of alternative hormones on the root ability of Parkia biglobosa. Sci. Agri., 13 (2):113-118.

Eid, A.M.H., Nomier, A. Safaa, M.M. Ibrahim, and M.M. Gad, 2018. Effect of some natural extracts, indolebutyric acid and naphthalene acetic acid on rooting of Picual olive cuttings. Zagazig J. Agric. Res., 45(1):119-136.

El-Botany, El-Shimaa M. and M.M.S. Saleh, 2018. Effect of some natural substances on grape cutting rooting. Middle East J. Agri. Res., 7(4):1702-1709.

El-Fouly, Amal S., Abdel-Fattah, H. Gehan and M.Y. Abdalla, 2009. Rooting semi-hard wood stem cuttings of Ficus deltoidea Jack plant. J. Agric. Sci. Mansoura Univ., 34(2):1107-1120.

El-Sayed, Boshra A., Ahmed, Samira S. and S.M. Shahin, 2010 a. Effect of biofertilizer, humic acid, indole-3- butyric acid and their interactions on rooting of some ornamental plants. I. Rose of China (Hibiscus rosa- sinensis L.). Egypt. J. Appl. Sci., 25(8A):485- 496.

El-Sayed, Boshra A., Ahmed, Samira S. and S.M. Shahin, 2010b. Effect of biofertilizer, humic acid, indole-3- butyric acid and their interactions on rooting of some ornamental plants. II. Paper flower (Bougainvillea glabra Choicy). Egypt. J. Appl. Sci., 25 (8A): 497-507.

Esmail, Sanaa A., 2008. Physiological studies on croton plant. PhD. Thesis, Ornamental Hort. Dept., Fac. Agric., Cairo Univ., Egypt.

Gad, M.M. and M.M. Ibrahim, 2018. Effect of IBA and some natural extracts on rooting and vegetative growth of Picual olive sucker and shoot cuttings. Current Science International, 7(2): 191- 203.

Goda, S.A., M.H. El-Shakhs, and Soliman, Amira Sh., 2018. Influence of planting dates and some chemical substances on rooting of Phytolacca dioica. Scientific J. Flowers \& Ornamental Plants, 5(4):309-321.

Gomes, E.N., L.M. Vieira, J. de Tomasi, C., Tomazzoli, M. Maria, R.L. Grunennvaldt, C.M. Fagundes, and C.B. Machado, 2018. Brown seaweed extract enhances rooting and roots growth on Passiflora actinia Hook stem cuttings. Ornam. Hortic., 24 (3): 269-276. 
Hameed, Raghad L. and Adil, Asmaa M. , 2020. Effect of wounding, auxins and cinnamon extract on the rooting and vegetative growth characteristics of Bottle Brush plant (Melaleuca viminalis $\mathrm{L}$.) cuttings. Scientific J. Flowers \& Ornamental Plants, 6(2):105-111.

Hartmann, H.T., D.E. Kester, F.T. Davies, and R.I. Geneve, 2002. Plant Propagation Principles and Practices. $7^{\text {th }}$ Ed., Prentice Hall International, New Delhi.

Herbert, D., P.J. Phillips, and R.E. Strange, 1971. Determination of total carbohydrates. Methods in Microbiol., 5(8): 290 - 344.

Huxley, A. ed., 1992. New RHS Dictionary of Gardening. Macmillan, 665.

Ibrahim, O.H.M., 2020. Developing air layering practices for propagation of Dracaena marginata Lam. utilizing phloroglucinol and seaweed extract as IBA-synergists or alternatives. Scientific J. Flowers \& Ornamental Plants, 7(2):185-197.

Ibrahim, Soad M.M., Taha, Lobna S. and M.M. Farahat, 2010.Vegetative growth and chemical constituents of croton plants as affected by foliar application of benzyl adenine and gibberellic acid. Journal of American Science, 6(7): 126-130.

Jackson M.H., 1973. Soil Chemical Analysis, Prentice Hall of India Private, Limited M- 97, New Delhi, India, 498.

Jena T.K., 2016. Effect of higher $\mathrm{CO}_{2}$ concentration on photosynthesis in Codiaeum variegatum under different sky conditions. International Journal of Engineering Research, 5(2): 107-109.

Kupchan, S.M., I. Uchida, A.R. Branfman, R.C. Dailey, and B.Y. Fei, 1976. Antileukemic principles isolated from Euphorbiaceae. Plants. Sci., 191:571-572.

Larsen, P., A. Harbo, S. Kungsan, and T.C. Asheim, 1962. On the biogenesis of some indole compounds in Acetobacrer xylinum. Plant Physiol., 15: 552-562.

Lun, L. J., 2016. Functional properties of wastes from cabbage (Brassica oleracea L. var. capitata) and capsicum (Capsicum annuum L. var. annum). B. Sc. Degree, Biomedical Science Dept., Fac. Science, Tunku Abdul Rahman Univ., 1-99.

Mabizela, G.S., M.M. Slabbert, and C. Bester, 2017. The effect of rooting media, plant growth regulators and clone on rooting potential of honeybush (Cyclopia subternata) stem cuttings at different planting dates. South Afri. J. Botany, 110:75-79.

Massoud, Hekmat Y.A., M.M. Abd El-Baset, and A.A. Ghozzy, 2017. Effect of some natural products as an alternative chemical growth regulators on rooting response, growth and chemical composition of rosemary cuttings. J. Plant Production, Mansoura Univ., 8 (8):797- 803.

Mead R., R.N. Curnow and A.M. Harted, 1993. Statistical Methods in Agriculture and Experimental Biology. $2^{\text {nd }}$ Ed., Chapman \& Hall Ltd., London, UK., 335.

Pacholczak, A. and K. Nowakowska, 2020. The effect of biostimulators and indole-3-butyric acid on rooting of stem cuttings of two ground cover roses. Acta Agrobotanica, 73(1):1-7.

Paradikovic, N., T. Teklic, S. Zeljkovic, M. Lisjak, and M. Spoljarevic, 2018. Bio-stimulants research in some horticultural plant species- A review. Food and Energy Security, 8:1-17.

Prieto, P., M. Pineda, and M. Aguilar, 1999. Spectrophotometric quantitation of antioxidant capacity through the formation of phosphomolybdenum complex: specific application to the determination of vit. E. Analy. Biochem., 269:337-341.

Rajan, R.P. and G. Singh, 2021. A review on the use of organic rooting substances for propagation of horticulture crops. Plant Archives, 21 (1): 685-692.

Saglam, A.C., S. Yaver, I. Baser, and L. Cinkilic, 2014. The effect of different hormones and their doses on rooting of stem cutting in Anatalian sage (Salvia fruticosa mill.). APCBEE Procedia, 8:348353.

Salim, H.H., M.A. Fayak, and A.M. Sweidan, 1978. Reproduction of Bircher apple cv. by layering. Ann. Agric. Sci., Moshtohor, 9: 157-166.

Sana, S., S. Mathew, and R.S. Krishnapriya, 2012. Organogenesis and somatic embryogenesis in various cultivars of Codiaeum variegatum L. Global Advan. Res. J. Biotechnol., 1(3): 40-47.

Sevik, H., K. Guney, O. Topacoglu, and C. Unal, 2015. The influences of rooting media and hormone applications on rooting percentage and some root characters in Schefflera arboricola. Inter. J. Pharmaceutical Science Invention, 4(2):25-29. 
Sitthithaworn, W., T. Yeepoosri, W. Yeepoosri, K. Mundee, and D. Vannavanich, 2011.The effect of bio-extract from cabbage waste on growth, yield and quality of volatile oil extracted from Mentha spicata and Mentha arvensis var. piperascens. Journal of Medicinal Plants Research, 5(9):1673-1676.

Silva, F.A.S. and C.A.V. Azevedo, 2016. The Assistant Software, Ver. 7.7 and its use in the Analysis of Experimental Data. Afr. J. Agric. Res., 11(39):3733-3740.

Singh, K. K., J.M.S. Rawat, and Y.K. Tomar, 2011 a. Influence of IBA on rooting potential of torch glory (Baugainvillea glabra) during winter season. J. Hort. Sci. \& Ornam. Plants, 3(2):162165.

Singleton, V.L., R. Orthofer, and R.M. Lamuela-Raventos, 1999. Analysis of total phenols and other oxidation substances and antioxidants by means of Folin Ciocalteu reagent. Methods in Enzymology, 299:152-178.

Soundy, P., K.W. Mpati, and E.S. Du Toit, 2008. Influence of cutting position, medium, hormone and season on rooting of fever tea (Lippia javanica I.) stem cuttings. Medicinal and Aromatic Plant Science and Biotechnology, 2(2):114-116.

Steel R.G. and J.H. Torrie, 1980. Principles and Procedures of Statistics. McGraw Hill Book Co., Inc., New York, 377- 400.

Sumanta, N., C.I. Haque, J. Nishika, and R. Suprakash, 2014. Spectrophotometric analysis of chlorophyllous and carotenoids from commonly grown Fern sp. by using various extracting solvents.Research J. Chem. Sci., 4(9):63- 69.

Taylor, J.L. and J.V. Staden, 1998. Plant-derived smoke solutions stimulate the growth of Lycopersicon esculentum roots in vitro. Plant Growth Regulation, 26(2):77-83.

Vuylsteker, C., E. Prinsen, J.P. Boutin, H.A.V. Onckelen, and S. Rambour, 1998. Evidence for nitrate reductase expression during initiation of lateral roots by NAA in chicory. J. Experimental Botany, 49(323):937-944.

Wide, S.A., R.B. Corey, J.G. Lyer, and G. Vioget, 1985. Soil and Plant Analysis for Tree Culture. $3^{\text {rd }}$ Ed., Oxford, IBH Publishing Co., New Delhi, 93-116.

Wikipedia site, 2021. https://en.wikipedia.org/wiki/Cabbage.

Woisky, R.G. and A. Salation, 1998. Analysis of propolis : some parameters and procedures for chemical quality control. J. Apiculature Research, 37:99-105. 